\title{
$\nabla$
}

\section{T-cell-predominant lymphoid hyperplasia in a tattoo*}

\author{
Erica Sales Souza ${ }^{1}$ \\ Everton da Silva Batista ${ }^{4}$ \\ Lourdes Farre ${ }^{4}$
}

\author{
Bruno de Oliveira Rocha ${ }^{2,3}$ \\ Rodrigo Ferreira de Oliveira ${ }^{2}$ \\ Achilea Lisboa Bittencourt ${ }^{5}$
}

\begin{abstract}
Cutaneous lymphoid hyperplasia (CLH) can be idiopathic or secondary to external stimuli, and is considered rare in tattoos. The infiltrate can be predominantly of B or T-cells, the latter being seldom reported in tattoos. We present a case of a predominantly T CLH, secondary to the black pigment of tattooing in a 35-year-old patient, with a dense infiltrate of small, medium and scarce large T-cells. Analysis of the rearrangement of T-cells receptor revealed a polyclonal proliferation. Since the infiltrate of CLH can simulate a T lymphoma, it is important to show that lesions from tattoos can have a predominance of T-cells.
\end{abstract}

Keywords: Lymphoma; Pseudolymphoma; Tattooing

Cutaneous lymphoid hyperplasia (CLH) can be idiopathic or secondary to various external stimuli, and is considered a rare occurrence in tattoos. ${ }^{1}$ Nihal et al (2003), in a review of 44 cases of CLH, found only one case due to tattooing. ${ }^{2}$ In this report, a case of Tcell-predominant CLH in a tattoo is described.

A 35-year-old woman presented with a history of pruritic lesions over a tattoo. The tattoo was done about five years ago and the lesion appeared four and a half years later. She referred prolonged sun exposure on weekends. Physical examination revealed a butterfly-shaped tattoo with red, black and yellow pigments in the interscapular region. There was a linear, erythematous, scaly plaque on one of the tattoo edges, corresponding to the red and black pigments (Figure 1 A). Histological examination showed epidermis with acanthosis, parakeratosis and foci of spongiosis and mild epidermotropism. In the upper and mid dermis, there was a dense infiltrate of small, medium and rare large lymphocytes, with irregular contours and some histiocytes and plasma cells (Figure 2A and 2B). The same infiltrate was present deeper around vessels and adnexae, and between collagen fibers (Figure 2C). Macrophages with black pigment, and less frequently with red pigment, were observed amidst the infiltrate. The black pigment was also seen in the interstitium. T-cells, UCHL-1+, CD2+, $\mathrm{CD} 3+$, and CD4+ represented around $90 \%$ of the infiltrate, with some CD20+ lymphocytes, a small number of CD79a+ plasma cells and CD68+ histiocytes (Figure 2D). CD1a was focally positive. Proliferative index evaluated by Ki-67 was around $10 \%$. Analysis of the rearrangement of the genes that codify the T-cell receptors in the skin lesion was performed according

Approved by the Advisory Board and accepted for publication on 11.11.2013.

Work performed at the Services of Dermatology, Complexo Hospitalar Universitário Prof. Edgard Santos, Federal University of Bahia (UFBa) - Salvador (BA), Brazil. Conflict of interest: None

Financial funding: None

Private clinic - Salvador (BA), Brazil.

Universidade Federal da Bahia (UFBa) - Salvador (BA), Brazil.

University of Toronto (UofT) - Toronto (ON), Canada.

Fundação Oswaldo Cruz (FioCruz) - Salvador (BA), Brazil

Conselho Nacional de Desenvolvimento Científico e Tecnológico (CNPq - Brasília (DF), Brazil.

(C)2014 by Anais Brasileiros de Dermatologia 


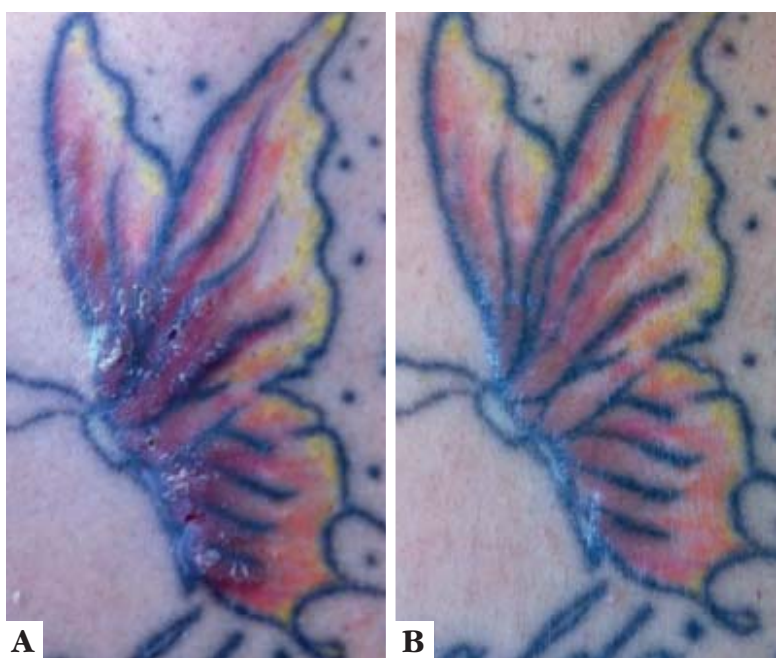

FIGURE 1: (a) Linear erythematous scaly plaque in areas with red and black pigments; (b) improvement of the desquamative component of the lesion, with maintenance of infiltration, after using topical corticosteroids

to a previously established method, and a polyclonal expansion of the T lymphocytes was observed. ${ }^{3}$

The diagnosis was a T-cell predominant CLH. Treatment with topical corticosteroids caused a partial improvement of the lesion and associated symptoms, with worsening after discontinuation of the therapy (Figure $1 \mathrm{~B}$ ).

In this case, the clinical lesions were similar to those described in the literature. ${ }^{4}$ Additionally, the precipitating factor may have been the intense sun exposure, associated with excessive sweating, as previously reported. ${ }^{1,5}$

CLH may represent a mixture of B and T-cells or have a predominance of one of these lymphocytes. T-cell-predominant CLH occurs much less frequently. ${ }^{2}$ In the present case, there was a marked predominance of T-cells CD4+, present in around $90 \%$ of the infiltrate. Contrasting with this observation, some of the literature mentions that CLH related to tattoos generally presents a predominance of B-cells. ${ }^{6,7}$ However, other cases in the literature also reveal T-cell-predominant CLH. ${ }^{1,8}$

CLH, previously called pseudolymphomas, can be erroneously diagnosed as cutaneous lymphomas, which is an important differential diagnosis. The present case showed a predominant $\mathrm{T}$-cell infiltrate with $\mathrm{CD} 2+, \mathrm{CD} 3+, \mathrm{CD} 4+, \mathrm{CD} 5+$, and CD8- mature cells, with some lymphocytic atypias, a moderate degree of proliferative index and a T-cell infiltrate dissociating the collagen fibers. These aspects could favor the diagnosis of cutaneous T-cell lymphoma. However, the clinical data, frequent presence of pigment in microscopy and polyclonality observed in the analysis of the T-cell receptor gene rearrangement, made the
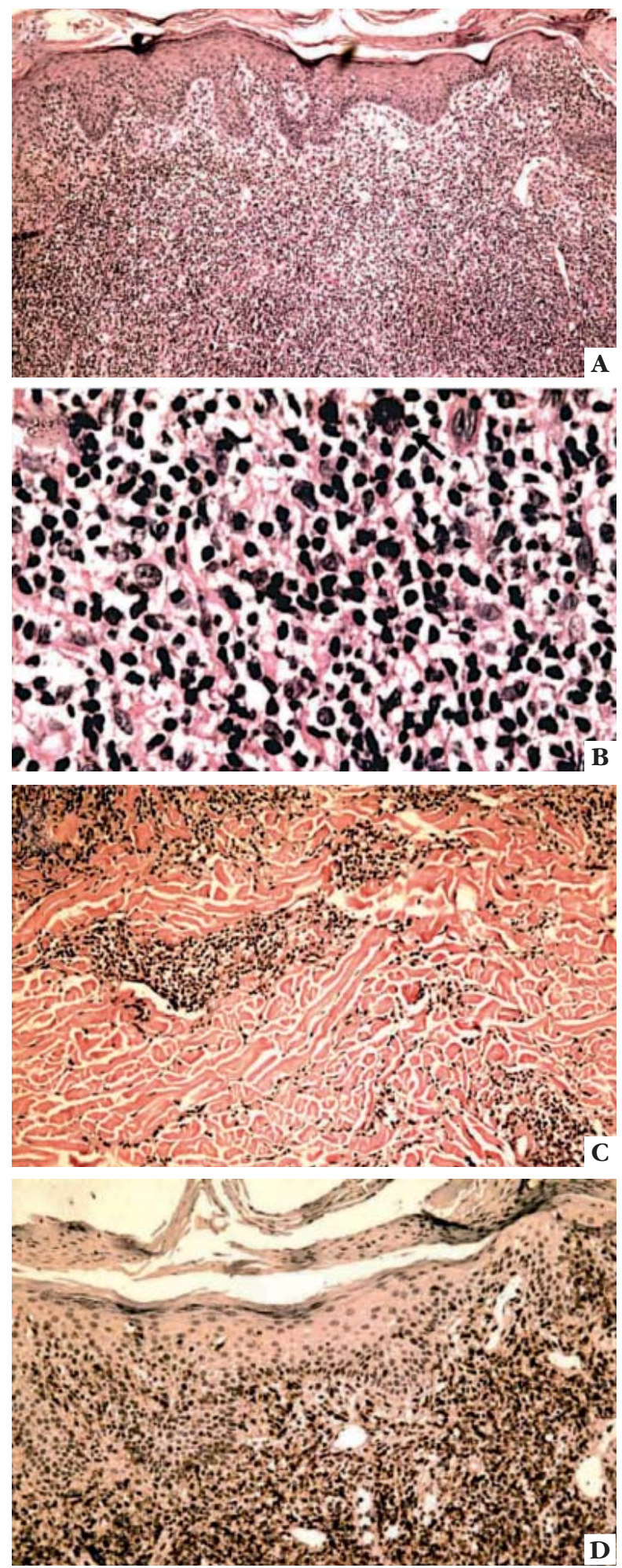

FIGURE 2: (a) Diffuse infiltration of lymphoid cells in the upper and mid dermis (HE, 64X); (b) nuclear pleomorphism of lymphocytes (HE, 500X); (c) deeply interstitial infiltration of lymphocytes between collagen fibers (HE, 100X); (d) marked predominance of T-cells (UCHL-1, 125X) 
differential diagnosis easier, thus permitting differentiation between CLH and cutaneous lymphoma.

Red pigment is considered the main cause of CLH in tattoos.' Nevertheless, the present case involved higher quantities of black pigment than red pigment. Reaction to black pigment was recently reported by Calpomi et al. ${ }^{8}$ In this context, the lesion's relapse after discontinuation of topical steroids is probably due to the presence of this pigment, perpetuating the reaction.

\section{REFERENCES}

1. Chiang C, Romero L. Cutaneous Lymphoid Hyperplasia (Pseudolymphoma) in a Tattoo after Far Infrared Light. Dermatol Surg. 2009;35:1434-8.

2. Nihal M, Mikkola D, Horvath N, Gilliam AC, Stevens SR, Spiro TP, et al. Cutaneous lymphoid hyperplasia: a lymphoproliferative continuum with lymphomatous potential. Hum Pathol. 2003;34:617-22.

3. Diss TC, Watts M, Pan LX, Burke M, Linch D, Isaacson PG. The polymerase chain reaction in the demonstration of monoclonality in T cell lymphomas. J Clin Pathol. 1995;48:1045-50.

4. Kazandjieva J, Tsankov N. Tattoos: dermatological complications. Clin Dermatol. 2007;25:375-82.

5. Blumental G, Okun MR, Ponitch JA. Pseudolymphomatous reaction to tattoos. Report of three cases. J Am Acad Dermatol. 1982;6:485-8.

6. Ploysangam T, Breneman DL, Mutasim DF. Cutaneous pseudolymphomas. J Am Acad Dermatol. 1998;38:877-95.

7. Gilliam AC, Wood GS. Cutaneous lymphoid hyperplasias. Semin Cutan Med Surg. 2000;19:133-41.

8. Campolmi P, Bassi A, Bonan P, Cannarozzo G, Gola M, Rossi Degl'Innocenti D, et al. Cutaneous pseudolymphoma localized to black tattoo. J Am Acad Dermatol. 2011;65:e155-7.

9. Sowden JM, Byrne JP, Smith AG, Hiley C, Suarez V, Wagner B, et al. Red tattoo reactions: X-ray microanalysis and patch-test studies. $\mathrm{Br} J$ Dermatol. 1991;124:576-80.

10. Bittencourt AL, Farre L. Leucemia/linfoma de células T do adulto (Adult T-cell leukemia/lymphoma). An Bras Dermatol. 2008;83:351-9.
In T-cell-predominant CLH, differential diagnosis must be done with cutaneous T-cell lymphoma, lymphomatoid contact dermatitis, lymphomatoid reaction to drugs and lymphoid hyperplasia caused by scabies. In the reported case, however, the clinical data made it possible to rule out these differential diagnosis. ${ }^{7,10}$

In order to avoid diagnostic errors, it is important to consider that CLH in a tattoo can also present a predominance of T-cells.

\author{
MAILING ADDRESS: \\ Bruno de Oliveira Rocha \\ Serviço de Dermatologia, Ambulatório Magalhães Neto \\ Rua Padre Feijó, 240, $3^{\circ}$. Andar \\ Canela \\ 40.110-170 - Salvador - BA \\ Brazil \\ E-mail: brunorocha.17@hotmail.com
}

How to cite this article: Souza ES, Rocha BO, Batista ES, Oliveira RF, Farre L, Bittencourt AL. T-cell-predominant Lymphoid Hyperplasia in a Tattoo. An Bras Dermatol. 2014;89(6):1019-21. 